\title{
'Winter ulcer' in the Atlantic salmon Salmo salar. Pathological and bacteriological investigations and transmission experiments
}

\author{
Tor Lunder $^{1}$, Øystein Evensen ${ }^{2, *}$, Gudmund Holstad $^{3}$, Tore Håstein ${ }^{1}$ \\ ${ }^{1}$ Department of Fish Health, Central Veterinary Laboratory, PO Box 8156 Dep., N-0033 Oslo, Norway \\ ${ }^{2}$ Department of Pathology, Central Veterinary Laboratory, PO Box 8156 Dep., N-0033 Oslo, Norway \\ ${ }^{3}$ Department of Microbiology and Immunology, Norwegian College of Veterinary Medicine, PO Box 8146 Dep., \\ N-0033 Oslo, Norway
}

\begin{abstract}
The present study describes pathological changes and bacteriological findings in 'winter ulcer' in Atlantic salmon Salmo salar L. The transmissibility of the disease was also evaluated under experimental conditions. Skin changes were characterized by ulcers of varying size, and were categorized as acute to subacute, chronic, and regenerative/reparative. In the acute stages, lesions were superficial with scale loss and mild inflammation, while in the subacute stages ulcers were present that extended down to the underlying muscle. Histologically, the chronic stages were characterized by a severe inflammation of the dermis and of the interstitial muscle tissue. In the regeneration/reparation stages, a hyperplastic epidermis covered granulation tissue. Bacteriological investigations carried out in salmon sampled from 8 different farms with winter ulcer identified 2 groups of bacteria that were common in affected fish. The examinations performed in the present study indicate that both these groups belonged to the genus Vibrio, termed sp. 1 and sp. 2, respectively. Immunohistochemically, Vibrio sp. 1 and 2 were identified in situ associated with muscle tissue degeneration. Experimental infection with Vibriosp. 1 induced a disease similar to winter ulcer in Atlantic salmon, while inoculation with Vibrio sp. 2 had no effect. Cohabitation experiments showed that winter ulcer can be transmitted from diseased to healthy individuals, and that injection was not required to induce the process. However, mechanical skin lesions were a predisposing factor for ulcer formation. The present study provides evidence that winter ulcer is caused by an infection with a Vibrio-like bacterium, and that the disease can be transmitted through cohabitation and injection. Pathological changes were not pathognomonic, and the severity of changes varied.
\end{abstract}

KEY WORDS: Salmon $\cdot$ Ulcer $\cdot$ Vibrio $\cdot$ Infection

\section{INTRODUCTION}

'Winter ulcer' or 'cold-water ulcer' is a disease that affects farmed Atlantic salmon Salmo salar L. in sea water (Lunder 1990, Thorud et al. 1990). The disease, which has been recognized since the early 1980s, is most frequently observed during the winter months when water temperatures are low (Lunder 1990). Winter ulcer was reported in 50 Norwegian fish farms during 1990 (Anonymous 1991). The mortality is usually

\footnotetext{
- Addressee for reprints
}

low, less than $10 \%$ during an outbreak, and fish that survive recover in spring when the sea water temperature rises above $8^{\circ} \mathrm{C}$.

The etiology of the disease has, so far, not been clarified. The most recent study on winter ulcer proposed that the skin lesions develop as a result of vascular thrombosis of dermal vessels which produces vesicle formation, followed by mechanical disruption (Salte et al. 1994). A further suggestion was that high levels of dietary iron could be a central factor. The possibility of an infectious etiology has not received any attention, although skin ulcers in Atlantic salmon have been linked to infection with a Cytophaga-like bacterium 
(Kent et al. 1988). The importance of mechanical skin damage as a predisposing factor for the formation of skin ulcers has been recognized with Cytophaga infections.

The purpose of the present study was to describe the pathological changes and preliminary bacteriological findings associated with winter ulcer, and to evaluate the transmissibility and infectivity of the disease.

\section{MATERIALS AND METHODS}

Fish sampling. Atlantic salmon included in this study originated from 8 different fish farms in Norway (Fig. 1). Fish were sampled during outbreaks of winter ulcer. At the time of sampling the disease was in its initial phase on farms $A$ and $B$, at the height of an outbreak on farms $C, D, E, F$, and $H$, and in a phase of recovery on farm $G$. All sampling was performed by local veterinary practitioners.

Altogether, 169 fish were collected randomly from lots with and without visible signs of winter ulcer. The number of fish sampled on each farm varied from 8 (farm F) to 30 (farm A), and the weights of the fish ranged from 70 to $3000 \mathrm{~g}$. The fish had been kept in tanks or net pens. All fish had been fed commercially available standard dried pellets according to standard regimes, and the fish had been transferred to sea water 5 to 21 mo prior to sampling. The frequency of fish with winter ulcer at the different farms ranged from 1 to $50 \%$. Mortalities during the disease period ranged from 0 to $2 \%$ per week. Fish with winter ulcer were observed on the fish farms for a period of 2 to 5 mo. The

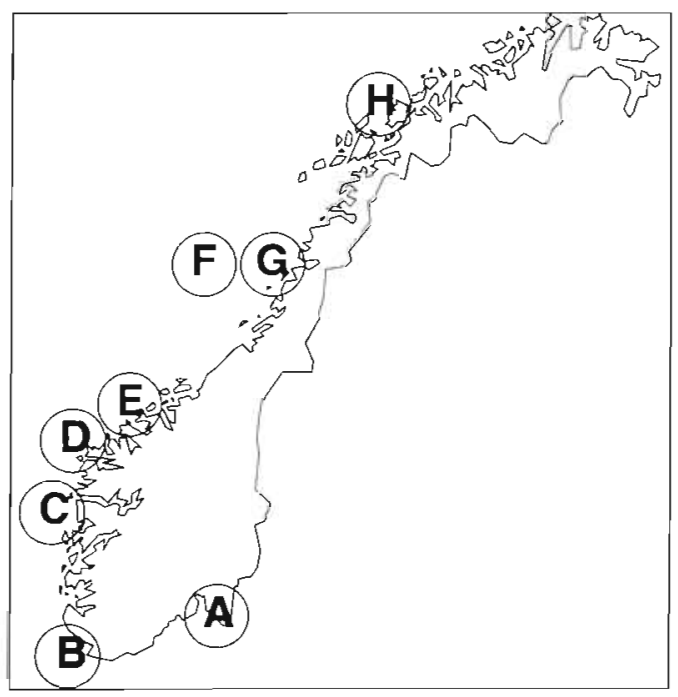

Fig. 1. Location of the 8 fish farms (A to $G$ ) in Norway at which sampling was carried out water temperature ranged from 4 to $8^{\circ} \mathrm{C}$ during the sampling period.

Other disease problems on the farms. Costiasis had been diagnosed on farms $E$ and $G$, while vibriosis and infection with atypical Aeromonas salmonicida had also been demonstrated in the summer period on farm G. Salmon lice (Lepeophtheirus salmonis and Calligus elongatus) infections were also diagnosed on farms $E$ and $\mathrm{G}$

Vaccination. Most fish on all farms had been vaccinated against cold-water vibriosis and vibriosis.

Pathology. Each fish was killed by a blow on the head. External lesions were recorded by one person only, and tissue samples were collected from skin and underlying muscle, liver, spleen, and kidney. Samples were fixed by immersion in 10\% neutral buffered formalin, $\mathrm{pH} 7.2$, and embedded in paraffin wax according to standard procedures. Parallel sections were cut at 5 to $6 \mu \mathrm{m}$ and stained with hematoxylin and eosin, hematoxylin and orange $\mathrm{G}(\mathrm{HO})$, periodic acid Schiff base, and Giemsa

Immunohistochemical studies. The immunohistochemical procedure employed was the avidin biotin complex (ABC) method (Hsu et al. 1981), modified as described by Evensen (1993). Sections from 10 different fish with skin ulcers that involved underlying muscle were investigated immunohistochemically. Two different antisera were used as primary antibodies, termed antiserum 1 and antiserum 2 (see below). The primary rabbit antisera were diluted in phosphate buffered saline (PBS) containing $12.5 \%$ bovine serum albumin $(w / v)$. The secondary antibody, anti-rabbit immunoglobulin (Dakopatts, Glostrup, Denmark), raised in goats and conjugated to biotin, was applied to the specimens at a dilution of 1:300. The sections were then incubated with avidin biotin alkaline phosphatase (Dakopatts, diluted 1:300), followed by incubation with Fast Red (0.1 $\mathrm{g} \mathrm{l}^{-1}$, Sigma, St. Louis, MO, USA) and naphthol AS-MX-phosphate $\left(0.2 \mathrm{~g} \mathrm{l}^{-1}\right.$, Sigma), with $1 \mathrm{mM}$ levamisole (Sigma) as inhibitor (to block endogenous alkaline phosphatase activity). After washing in tap water, the sections were counterstained with Mayer's hematoxylin for 2 min, washed in tap water, and 'coverslipped' with an aqueous mounting medium (Dakopatts).

The end-point dilution values of the primary antisera were determined, and defined as the highest dilution of the sera that gave a positive reaction which was distinguishable from background (Petrusz 1983).

The specificity of the reactions observed was tested using tissue sections of skin from fish experimentally infected exclusively with the homologous bacterium. Sections from mixed infections were also included. Samples of skin from healthy Atlantic salmon were used as controls. Heart muscle from Atlantic salmon 
infected with Vibrio salmonicida (Evensen et al. 1991) was also used to evaluate the specificity of the immune sera used.

Scanning electron microscopic (SEM) studies. Sections of skin ulcers were fixed in $3 \%$ glutaraldehyde buffered with $0.1 \mathrm{M}$ cacodylate, $\mathrm{pH} 7.3$. Thereafter, specimens were washed in the same buffer, postfixed for $4 \mathrm{~h}$ at room temperature in $2 \% \mathrm{OSO}_{4}$ in $0.1 \mathrm{M}$ cacodylate buffer, $\mathrm{pH} 7.2$, dehydrated in graded ethanols, critical point dried (Balzer CPD 020, Balzer Union Ltd, Balzers, Liechtenstein) using carbon dioxide as the transitional fluid, and coated with a $300 \AA$ layer of gold in a Polaron ${ }^{\circledR}$ E5 100 sputter coater (Polaron Equipment Ltd, Watford, UK). The specimens were examined in a Cambridge Stereoscan 90 scanning electron microscope.

Bacteriological investigations. The bacteriological examinations were carried out on blood agar (heart infusion agar, Difco Laboratories, Detroit, MI, USA, with $5 \%$ bovine blood containing 0.5 or $2 \% \mathrm{NaCl}$. The blood agar plates were incubated at 15 and $22^{\circ} \mathrm{C}$, and examined after $1,2,4$, and $7 \mathrm{~d}$. Material for inoculation was sampled from the kidneys of all individuals, and from the edge of the ulcers if such lesions were present. Salmon lice were collected from 6 of the fish farms with winter ulcer. Lice were also collected from 2 farms unaffected with winter ulcer disease. The parasites were removed from the fish with sterilized forceps, and bacteriological examination of the lower surface of the lice was carried out by swabbing the lice directly against the surface of the medium

The bacteria isolated were characterized according to methods described by West \& Colwell (1983). The identification tests used are listed in Table 1.

An enzyme-linked immunosorbent assay was used to test the reactivity of a monoclonal antibody specific for Vibrio salmonicida (Espelid et al. 1988) with the bacteria isolated from diseased fish. In addition, all isolated bacteria were examined serologically using a slide agglutination test with rabbit antisera raised against 2 different bacterial strains isolated from Atlantic salmon with winter ulcer (designated antiserum 1 and 2, respectively). The rabbit antisera were prepared by culturing the bacterial strains on blood agar plates containing $2 \% \mathrm{NaCl}$. The plates were incubated at $15^{\circ} \mathrm{C}$ for $24 \mathrm{~h}$, and harvested bacteria were then washed in PBS, pH 7.3. Bacteria resuspended in
PBS were standardized to an optical density $\left(\mathrm{OD}_{525}\right)$ of 0.65 . A volume of $2 \mathrm{ml}$ of formalin-killed cells prepared from these suspensions was injected intravenously at Days 1, 4, and 7 , while $0.1 \mathrm{ml}, 0.5 \mathrm{ml}$, and $1 \mathrm{ml}$ living cells were injected at Days 12,15 , and 20, respectively. The sera were collected at Day 28.

Cohabitation experiments. The cohabitation experiment was performed by combining diseased and healthy fish together in 2 replicate tanks (see below). Diseased fish (Group 1) were collected during a natural outbreak of winter ulcer and were transported to the experimental facilities at the start of the experiment. The healthy fish (Group 2, average weight of $250 \mathrm{~g}$ ) originated from a smolt farm on which winter ulcer had not been diagnosed. The fish had been kept in sea water for 5 mo prior to the onset of the experiment. The healthy fish were transported directly to the experimental station from the smolt farm, and showed no signs of winter ulcer at the start of the experiment.

Five diseased fish (Group 1) were placed together with 5 healthy adipose fin-clipped Atlantic salmon (Group 2) in each of 2 tanks, I and II. At Day 7, 5 healthy non-marked Atlantic salmon (Group 3) were placed in each of the 2 tanks. A group of 10 Atlantic salmon (not adipose fin-clipped) were kept in a separate tank and served as control fish.

Each tank contained $200 \mathrm{l}$ of sea water and was continuously supplemented with sea water at $10^{\circ} \mathrm{C}$. 
The fish were observed over a period of $30 \mathrm{~d}$. Bacteriological investigations were carried out on all the fish at the end of the experiment, and cultures were made from kidney and liver, and also from ulcers, if present.

Inoculation experiments. Atlantic salmon with an average weight of $37 \mathrm{~g}$ were used in this experiment. The fish originated from a smolt farm with no known history of winter ulcer, and the fish had been kept in fresh water prior to transfer to $10 \%$ brackish water 1 wk before the experiment started.

Ten individuals were examined microbiologically before the experiment started. Bacteriological investigations were all negative, as were tests for the presence of infectious pancreatic necrosis (IPN) virus and erythrocytic inclusion body syndrome virus.

The test Atlantic salmon were challenged with 2 different Vibrio spp., 1 and 2, both of which had been isolated from skin lesions of Atlantic salmon with winter ulcer. The bacteria were either used immediately after the primary isolation (Vibrio sp. 1) or after 2 subcultures (Vibrio sp. 2).

The vibrios were cultured on blood agar containing $2 \% \mathrm{NaCl}$. After incubation for $24 \mathrm{~h}$ at $15^{\circ} \mathrm{C}$, the plates were washed with sterile PBS, and the resulting bacterial suspensions used for inoculation. The dose per fish varied from $14 \mathrm{CFU}$ to $5 \times 10^{11} \mathrm{CFU}$. The number of CFU was determined by parallel counts of serial dilutions on blood agar.

Altogether 200 individuals were inoculated subcutaneously (SC) with Vibrio sp. 1 and 190 were inoculated (SC) with Vibrio sp. 2. Injections were performed between the adipose fin and the side line after sedation with $0.05 \mathrm{~g} \mathrm{l}^{-1}$ benzocaine. Control fish received an SC injection with saline.

Bacteriological investigations were carried out as described above. Cultures were made from kidney and liver, and also from skin ulcers, if present.

\section{RESULTS}

\section{Pathological findings}

Of the 169 fish examined macroscopically, 102 showed typical skin ulcers, while the remainder did not show signs of skin lesions.

Skin ulcers were found on the scale-covered part of the body, and were most frequently located along the side of the fish, between the adipose fin, dorsal fin, and the vent. The size of the skin lesions ranged from small and scarcely visible, to large ulcers covering about one third of the lateral body surface

Skin lesions were categorized as follows: acute to subacute, with superficial lesions extending down only to the stratum compactum; chronic, with lesions extending beyond the stratum compactum and down to the underlying muscle; and regenerative/reparative, with lesions showing granulation tissue covered with a scale-free hyperplastic epidermis.

Macroscopically, the acute and subacute lesions were superficial, and typically associated with scale loss (Fig. 2). Histologically, there were minor changes characterized by edema in the superficial loose connective tissue and a moderate, focal subepidermal infiltration of inflammatory cells (Fig. 3).

Chronic lesions most frequently showed severe ulceration that exposed the subcutaneous tissue and underlying muscle (Fig. 4); this gave the lesions a bright red colour. The muscle was, however, often covered with a greyish/white or yellow mucus-like layer Histologically, the deep ulcerative lesions extended beyond the stratum compactum to expose subcutaneous tissue and underlying muscle (Fig. 5). The inflammatory changes in the subcutaneous tissue varied from a moderate to a pronounced infiltration of inflammatory cells, which involved neutrophils and mononuclear cells (Fig. 6). Inflammatory changes were also present in the intermuscular connective tissue (Fig. 7), concurrently with a moderate fibroblast proliferation. Degenerative changes were observed in the muscle cells, with granulation of the sarcoplasm, discoid degeneration, and hyalinization of the muscle fibres (Fig. 8). Endothelial cell damage was occasionally found, and was associated with the presence of thrombus-like formations (Fig. 9). Bacteria were frequently observed at the edge of the ulcers, and also invading the muscle tissue close to the ulcers

Macroscopically, lesions undergoing regeneration/ reparation had a slightly hyperemic or bright red appearance. Re-epithelialization was also evident, and was characterized by scale-free areas covered by a partly or fully intact epidermis. On incision, the tissue was grey and slightly hyperemic. Histologically, these lesions were characterized by a conspicuous epithelial hyperplasia and an epidermis of varying thickness (Fig. 10). Scales were absent (Fig. 10), while granulation tissue was prominent in the subcutaneous and deep dermal tissue (Fig. 11). The inflammatory changes were moderate.

\section{Immunohistochemical studies}

Cross-reactions were observed using the 2 antisera. In fish infected with homologous bacteria, the endpoint dilution values obtained were 1:64000 and 1:8000 for antiserum 1 and 2, respectively. The corresponding values for fish infected with heterologous bacteria were $1: 16000$ and 1:2000. Positive reactions 

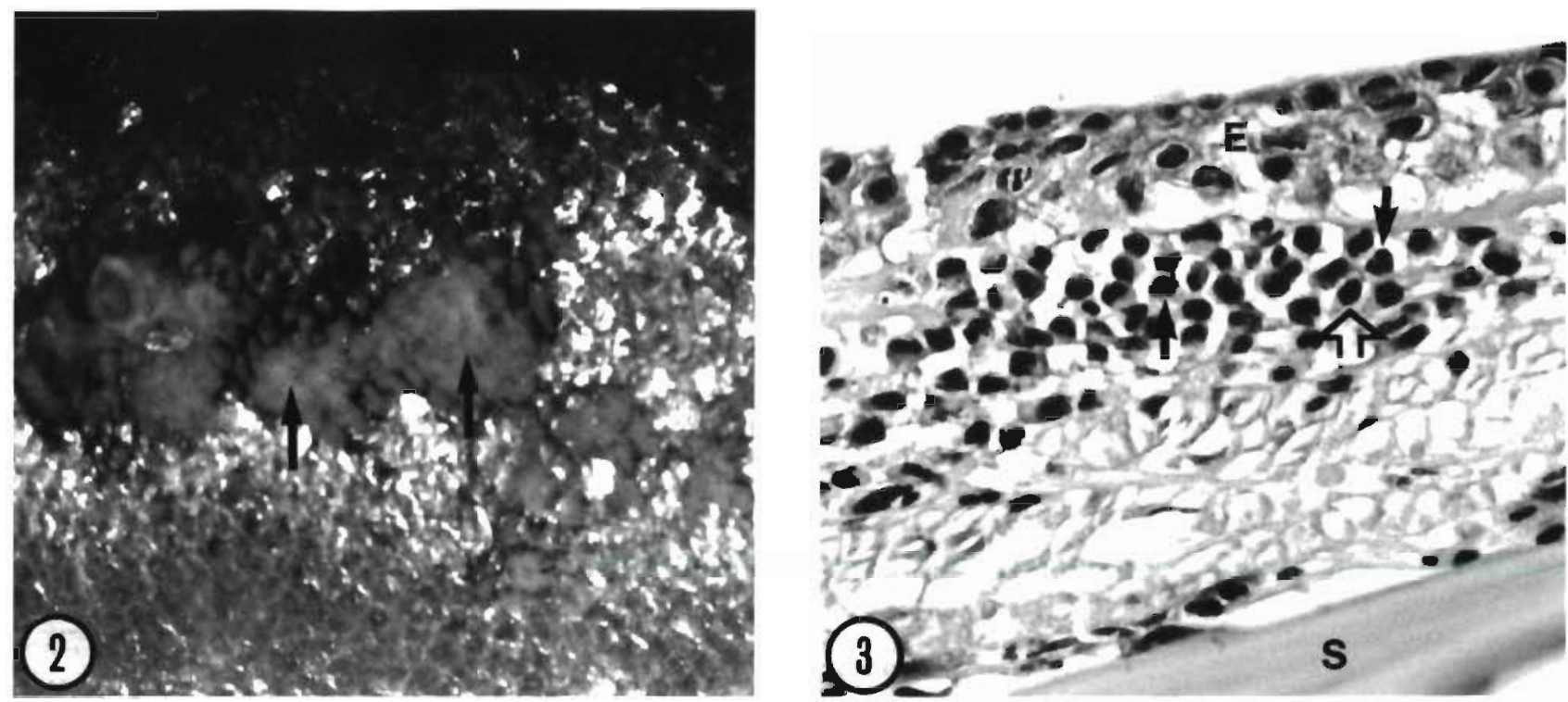

Figs. $2 \& 3$. Salmo salar. Acute lesions. Fig. 2. Gross lesions were characterized by erosions and moderate loss of scales leaving a greyish, subepidermal tissue (arrows). Fig. 3. Histologically, a moderate subepidermal edema was present; also there was focal infiltration of polymorphic granulocytes (arrows) and lymphocytes (open arrow). Epithelial cells (E) were vacuolated and there was a moderate intercellular edema. Desquamation is not apparent in this section. S: scale. $\times 133$. Hematoxylin/orange G (HO)

were obtained with both antisera in tissue sections from fish with mixed infections. The end-point values were the same as for homologous infections. Based on these results, a strong reaction with antiserum 1 at dilutions above $1: 16000$, and a negative reaction with antiserum 2 at dilutions above 1:2000, were considered to indicate an infection with Vibrio sp. 1. A negative reaction with antiserum 1 at dilutions above 1:16000 and a positive reaction with antiserum 2 at dilutions above 1:2000 were considered to indicate a Vibrio sp. 2 infection. No reactions were observed in tissue sections from normal fish or from fish infected with V. salmonicida.

Positive reactions were demonstrated in degenerate epithelium, in exposed stratum compactum in the dermis, and in exposed subcutaneous tissue. Positive reactions were also observed in the intermuscular tissue, and in association with degeneration and myolysis (Fig. 12). Of the 10 fish examined immunohistochemically, the results indicating an infection with Vibrio sp. 1 and/or Vibrio sp. 2 were in accordance with results obtained from the bacteriological examinations.

\section{SEM studies}

Scanning electron microscopy of the edge of the subacute skin lesions revealed elongated, curved bacteria of varying sizes in parts of the lesion (Fig. 13).

\section{Bacteriological examinations}

The bacteria isolated from diseased fish were of the Vibrio sp. and could be divided into 2 major groups, Vibrio sp. 1 and Vibrio sp. 2, according to the results of the tests carried out (Table 1).

Vibrio sp. 1 was not detectable after $1 \mathrm{~d}$ of incubation at 15 or $22^{\circ} \mathrm{C}$ during primary isolation. After $2 \mathrm{~d}$ of incubation, Vibrio sp. 1 appeared as small colonies, 0.5 to $1 \mathrm{~mm}$ in diameter, which showed either weak or no hemolysis. However, after $3 \mathrm{~d}$ of incubation, the colony diameter had reached 1 to $3 \mathrm{~mm}$ and $\beta$-hemolysis could easily be detected underneath the colonies. The colonies were greyish, transparent, rounded and even. They were very viscous and adherent to the agar surface. Vibrio sp. 1 did not grow on blood agar containing $0.5 \% \mathrm{NaCl}$. Antiserum 1 agglutinated only Vibrio sp. 1.

Vibrio sp. 2 showed pin-point colonies after $1 \mathrm{~d}$ of incubation, while the diameter ranged from 1 to $2 \mathrm{~mm}$ after $2 \mathrm{~d}$. The colonies were butyrous, yellow, rounded, with an opaque edge and could easily be removed from the agar surface. After $3 \mathrm{~d}$ of incubation, the colonies were surrounded by a $\beta$-hemolytic zone, although non-hemolytic variants were also seen. Hemolysis was only evident when the bacteria were grown on media containing $2 \% \mathrm{NaCl}$, i.e., not on media containing $0.5 \% \mathrm{NaCl}$. Most bacteria categorized as Vibrio sp. 2 were nevertheless able to grow slowly on blood agar containing $0.5 \% \mathrm{NaCl}$. Antiserum 2 agglutinated only Vibrio sp. 2. 


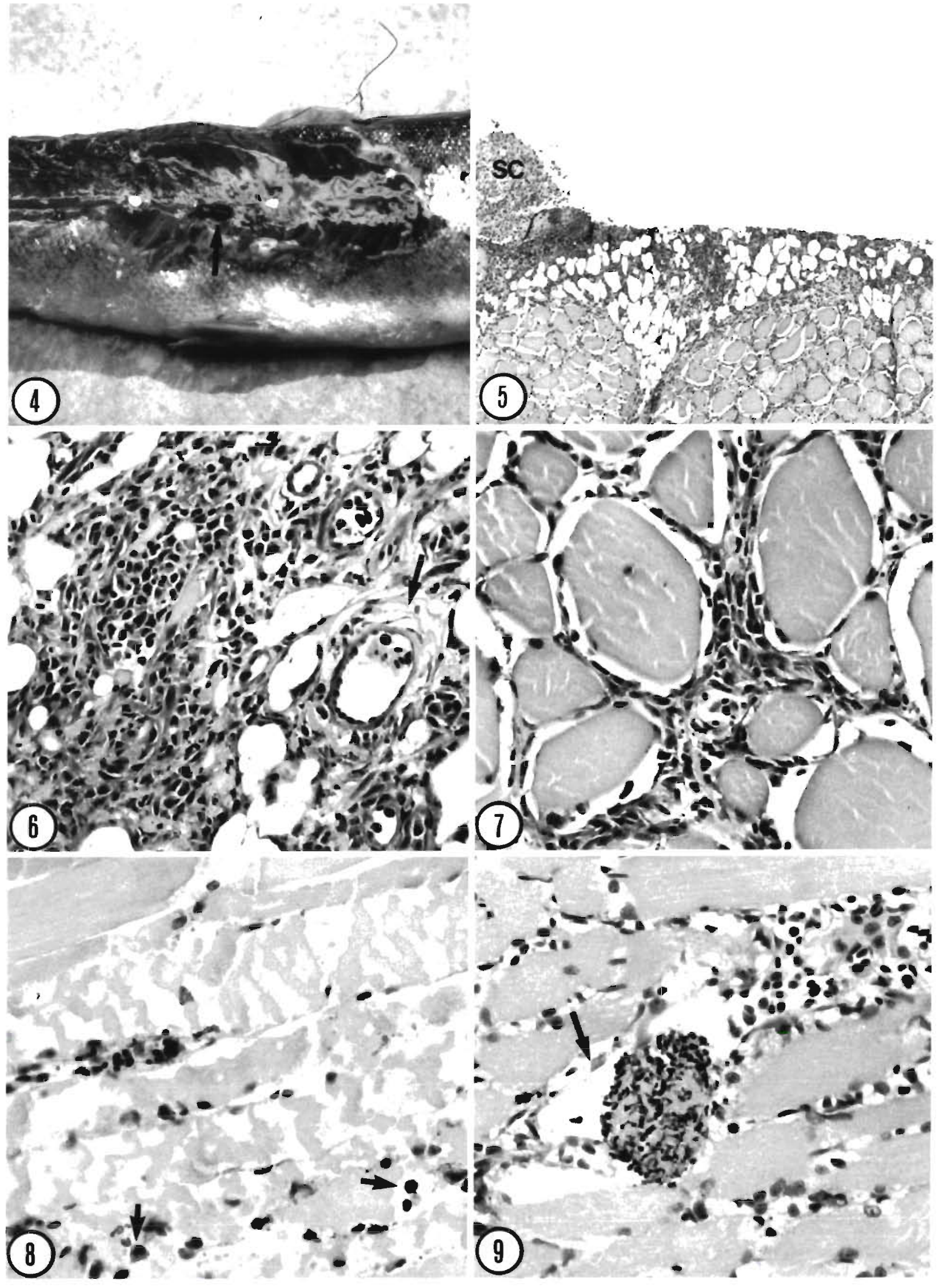


Figs. 4 to 9. Salmo salar. Chronic lesions. Fig. 4. A large, deep ulcer with exposed muscle tissue. Note salmon lice (arrow). Fig. 5. The ulcer extends to subcutaneous tissue which is heavily infiltrated with inflammatory cells. SC: stratum compactum. $\times 53$. HO. Fig. 6. Subcutaneous tissue beneath an ulcer is heavily infiltrated with polymorponuclear granulocytes and lymphocytes. A moderate perivascular edema is also present (arrow). $\times 333$. Fig. 7 . Moderate infiltration of mononuclear inflammatory cells in intermuscular connective tissues. $\times 533$. HO. Fig. 8 . Discoid degeneration and moderate infltration of mononuclear inflammatory cells (arrows) in muscle fibres. $\times 533$. Fig. 9 . Small thrombus in a venule, with moderate swelling of endothelial cells (arrow). $\times 533$. HO
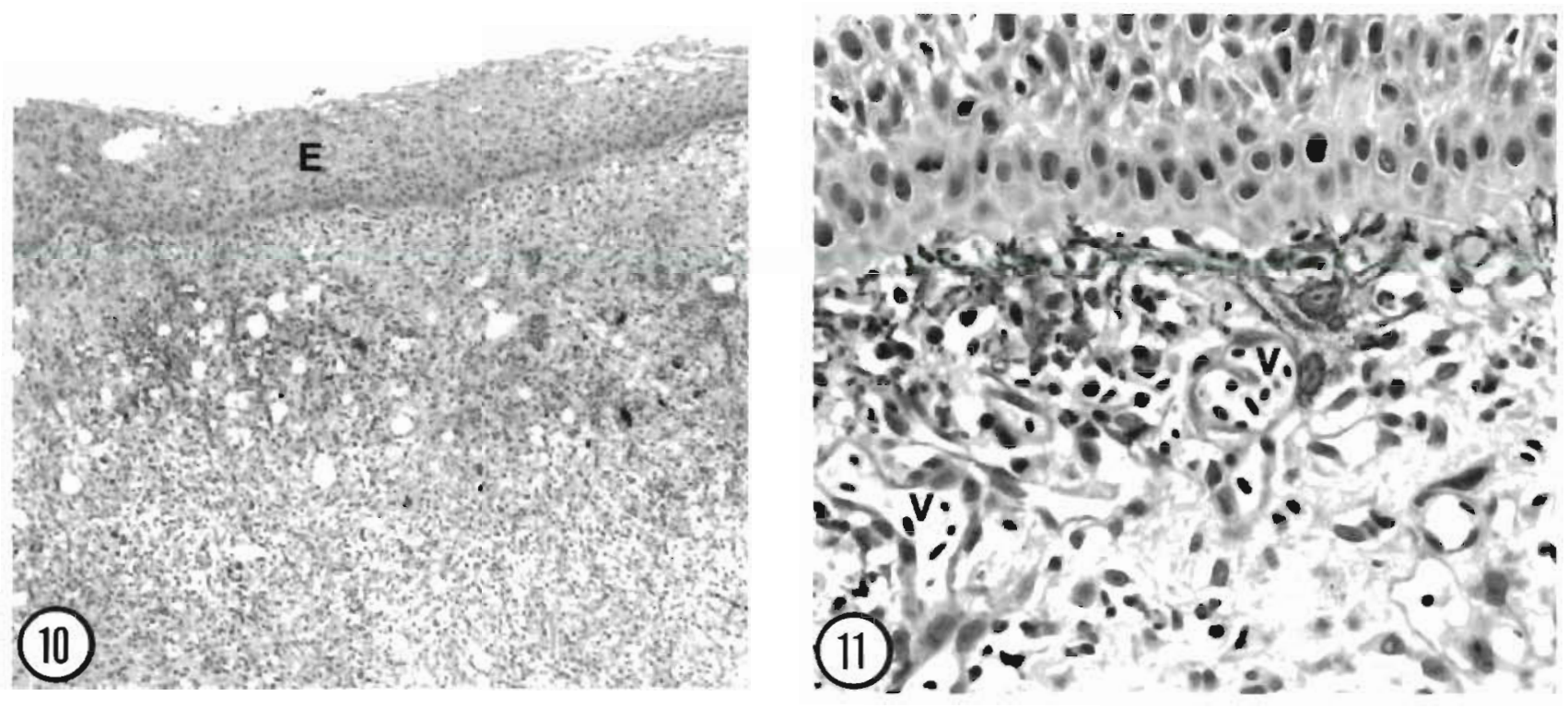

Figs. 10 \& 11. Salmo salar. Regenerative/reparative lesion. Fig. 10. Epidermis (E) varies in thickness and is scale-free. Fig. 11. Detail from same lesion showing prominent epidermal hyperplasia and highly vascularized (V) subepidermal, granulation tissue Pigment cells are also present $\times 533 . \mathrm{HO}$

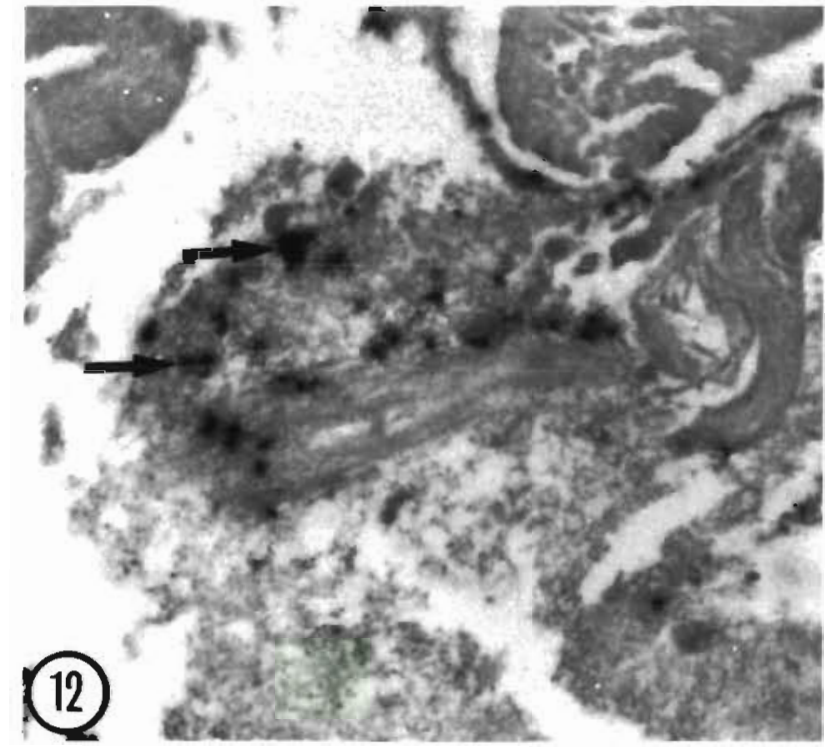

Fig. 12. Salmo salar. Chronic lesion. Immunohistochemical staining with antiserum 1 showing a specific, strong, granular reaction in a necrotic muscle fibre, both intra- and intercellularly, representing bacteria/bacterial products (arrows). $\times 533$ Counterstained with Mayer's hematoxylin

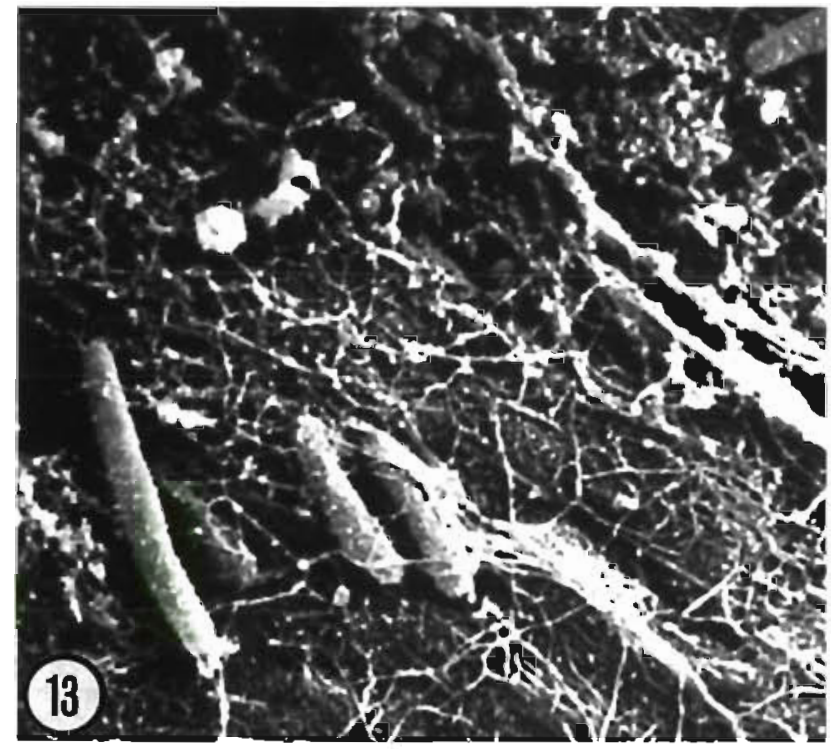

Fig. 13. Salmo salar. Chronic lesion. Scanning electron micrograph of degenerate muscle fibres showing superficially situated slender, long bacteria, located intercellularly and partially infiltrated in fibrinous exudate. $\times 4320$ 
Table 2. Bacteria isolated from skin ulcers and/or kidneys in different individuals of Salmo salar from 8 different fish farms with winter ulcer

\begin{tabular}{|c|c|c|c|c|}
\hline \multirow[t]{2}{*}{ Bacteria } & \multirow[t]{2}{*}{$\begin{array}{l}\text { No. of } \\
\text { fish farms }\end{array}$} & \multicolumn{2}{|c|}{$\begin{array}{l}\text { Fish with skin ulcers } \\
\qquad(\mathrm{n}=102)\end{array}$} & \multirow{2}{*}{$\begin{array}{l}\text { Fish without skin ulcers } \\
\qquad \begin{array}{l}(\mathrm{n}=67) \\
\text { Kidney } \\
\text { No. }(\%)\end{array}\end{array}$} \\
\hline & & $\begin{array}{l}\text { Ulcers } \\
\text { No. }(\%)\end{array}$ & $\begin{array}{l}\text { Kidney } \\
\text { No. }(\%)\end{array}$ & \\
\hline Vibrio sp. $1^{a}$ & 1 & $7(7)$ & $13(13)$ & $3(4)$ \\
\hline Vibrio sp. $2^{b}$ & 2 & $34(33)$ & $35(34)$ & $619)$ \\
\hline Both Vibrio sp. 1 and Vibriosp. $2^{c}$ & 5 & $60(59)$ & $29(28)$ & 0 \\
\hline Bacteria other than Vibrio sp. 1 and Vibrio sp. 2 & 0 & 0 & 0 & $4 \quad(6)$ \\
\hline No bacteria & 0 & $1(1)$ & $25(25)$ & $54(81)$ \\
\hline \multicolumn{5}{|c|}{ a Isolated in pure culture or mixed with bacteria other than Vibrio sp. 2} \\
\hline \multicolumn{5}{|c|}{${ }^{\mathrm{b}}$ Isolated in pure culture or mixed with bacteria other than Vibrio sp. 1} \\
\hline
\end{tabular}

Vibrio spp. 1 and/or 2 were isolated from skin ulcers of $101(99 \%)$ out of the 102 individuals examined (Table 2). In the vibrio-positive fish, bacteria of both types (1 and 2) were isolated from $59 \%$ of the individuals, while of Vibrio sp. 1 alone and Vibrio sp. 2 alone were obtained in 7 and $33 \%$ of these fish, respectively (Table 2)

Bacteria were isolated from the kidneys of $75 \%$ of the individuals. Vibrio spp. 1 and 2 dominated; ather bacteria were isolated only from fish with large skin ulcers, but always together with Vibrio sp. 1 and/or Vibrio sp. 2 (Table 2).

Vibrio salmonicida was detected in mixed culture with Vibrio sp. 1 and/or Vibriosp. 2 in samples from 12 individuals from farm $\mathrm{F}$.

\section{Salmon lice}

Vibrio sp. 1 and/or Vibrio sp. 2 were isolated from all salmon lice removed from fish with winter ulcer. In contrast, no Vibrio sp. 1 or Vibrio sp. 2 were cultured from lice originating from the in fish farms unaffected by winter ulcer.

\section{Cohabitation experiments}

All the diseased fish (Group 1) in both tanks died within $5 \mathrm{~d}$, while all the fin-clipped cohabitants (Group 2) developed typical skin ulcers within 2 to $4 \mathrm{~d}$ after the start of the experiment. The area around the injured adipose fin was the site most prone to development of skin lesions. The unmarked fish (Group 3) which were introduced on Day 7 in Tank I did not develop ulcers. In contrast, in Tank II, 2 unmarked fish developed skin ulcers, one of which died 2 wk (by Day 21) after being introduced into the tank.
Both Vibrio spp. 1 and 2 were isolated from skin ulcers of all fish in Groups 1 and 2, and from skin ulcers of the fish that died in Group 3. Vibrio sp. 1, however, dominated in cultures from the kidney and liver in these individuals. The CFU count was low. No bacteria were isolated from the control fish.

\section{Inoculation experiments}

Inoculation of $14 \mathrm{CFU}$ of Vibrio sp. 1 induced skin ulceration at the inoculation site, and resulted in mortality in $3 \%$ of the individuals ( 2 out of 60 died within 13 to $21 \mathrm{~d}$ ). Inoculation of $1.4 \times 10^{4} \mathrm{CFU}$ of the same bacterium induced ulcer formation at the inoculation site in all fish, and $18 \%$ (11 out of 60 ) of the individuals died during the same period. Inoculation with doses of $10^{6} \mathrm{CFU}$ or higher of the same strain caused $100 \%$ mortality within $5 \mathrm{~d}$. Vibrio sp. 1 was re-isolated from diseased and dead fish from all tissues investigated. The skin lesions were characteristic of winter ulcer.

Inoculation of up to $10^{9}$ and $10^{11}$ CFU of Vibrio sp. 2 failed to cause any skin ulceration or mortality. However, the skin became raised at the inoculation site 1 wk after injection, the swelling lasted for approximately $2 \mathrm{wk}$. In these fish, no pathological signs were observed at autopsy at the end of the experimental period, nor were bacteria detected.

\section{DISCUSSION}

The present study provides substantial evidence that winter ulcer is a disease in Atlantic salmon caused by infection with Vibrio-like bacteria. The cohabitation and inoculation experiments indicate that the disease can be reproduced under experimental conditions, and that injection is not required to cause disease and mor- 
tality. The pathology of the disease is not unique and is characterized by large skin lesions of varying size that often involve the underlying muscle. Immunohistochemically, bacteria can be identified in situ in skin and associated with pathological changes.

In the present study, the isolated bacteria were identified according to the methods described by West \& Colwell (1983), which were established for differentiating between marine bacteria. The 2 groups of Vibrio sp. bacteria were Gram-negative, motile rods, which metabolized glucose both oxidatively and fermentatively, produced oxidase, and were sensitive to the vibriostatic agent. These characteristics indicated that the bacteria in question belonged to the genus Vibrio (Bauman \& Schubert 1984).

Vibrio species reported to be pathogenic to fish include $V$. anguillarum, $V$. ordalii, $V$. vulnificus biotype $2, V$. damsela, $V$. alginolyticus, $V$. charcaria, $V$. cholera, $V$. parahaemolyticus, and $V$. salmonicida (Colwell \& Grimes 1984, Egidius et al. 1986). Features such as arginine dihydrolase, and arginine, lysine, and ornithine decarboxylases have been suggested as key characteristics for the differentiation of the Vibrio species (West \& Colwell 1983). Vibrio sp. 1 was positive to lysine decarboxylase, and negative to arginine dihydrolase, arginine decarboxylase and lysine decarboxylase, which are properties shared with $V$. vulnificus biotype 2 (Colwell \& Grimes 1984). Vibrio sp. 2 showed no dihydrolase/decarboxylase activities and in this regard was similar to $V$. salmonicida and $V$. ordalii (Schiewe et al. 1981, Holm 1985). Neither $V$. vulnificus biotype 2, $V$. salmonicida, nor $V$. ordalii showed slide agglutination with antisera 1 and 2 (Lunder unpubl.), and these findings indicate that neither of the 2 vibrio species isolated from fish with winter ulcer can readily be included among the known fish-pathogenic Vibrio species.

Vibrio sp. 1 and Vibrio sp. 2 were isolated from samples from all the fish farms investigated, and Vibrio sp. 2 bacteria were isolated most frequently. Inoculation experiments showed that Vibrio sp. 1 induced a disease similar to winter ulcer, and this bacterium was also most frequently isolated from diseased fish in the cohabitation experiment. In contrast to these findings, Vibrio sp. 2 failed to induce ulcers, and no mortality was observed after inoculation. This apparent difference between the results from the field isolation and from the inoculation experiments may be the result of different in vitro growth characteristics. Vibrio sp. 2 formed larger colonies, which were visible after only 1 $\mathrm{d}$ of incubation, compared to $2 \mathrm{~d}$ of incubation needed for the appearance of the smaller colonies of Vibriosp. 1. This slower growth may have resulted in an underestimation of the prevalence of Vibrio sp. 1. Additionally, for technical reasons, the infection experiments were run at $10^{\circ} \mathrm{C}$, which might also give suboptimal conditions with regard to establishing a skin infection. Even so, by immunohistochemistry, Vibrio sp. 1 was detected in skin lesions in association with degenerated and necrotic muscle cells, which suggests the production of tissue toxic enzymes. Vibrio sp. 1 was also hemolytic in vitro. Thus, the bacteriological findings from spontaneous outbreaks of winter ulcer, and the results from inoculation and cohabitation experiments, combined with the in situ detection of the bacteria, support the view that Vibrio sp. 1 is the etiologic agent. The significance of Vibrio sp. 2 bacteria for the development of winter ulcer, however, as mentioned, remains uncertain, but this group of bacteria may play a role as secondary invaders.

Pseudomonas fluorescence has been isolated from skin ulcers in rainbow trout where IPN virus was considered to be the primary agent (Roberts \& Horne 1978). IPN virus has been detected in $97 \%$ of all fish farms in Norway (Melby et al. 1991). This is a situation quite different from that for winter ulcer, which has only been recorded to a limited extent. A direct connection between the 2 disease entities therefore seems unlikely, although IPN virus may be a predisposing factor.

Skin ulcers have been described in fish species other than Atlantic salmon. In Atlantic cod Gadus morhua the ulcus syndrome (Jensen \& Larsen 1979) is a disease which displays gross lesions comparable to those seen in winter ulcer. The primary etiological agent of the ulcus syndrome in cod has been identified as an iridovirus (Jensen et al. 1979, Jensen \& Larsen 1982), and bacteria are rarely isolated in the early stages of the disease (Larsen \& Jensen 1979). These findings are in contrast to those reported for winter ulcer where bacteria are isolated in the early stages of the disease.

Bacterial cold-water disease caused by an infection with Flexibacter psychrophilus is a septicemic infection in young coho salmon Oncorhynchus kisutch that occurs in the northwest USA. Skin lesions are associated with this infection and they are typically located near the peduncle (Holt et al. 1993). Infection with $F$. psychrophilus in fresh water causes 'fry mortality syndrome' in rainbow trout Oncorhynchus mykiss (Lorenzen et al. 1991), while infection in adult fish produces skin ulcers (Pacha \& Ordal 1970, Lorenzen \& Karas 1992). So far, there are no indications that Flexibacter spp. are involved in the development of winter ulcer in Atlantic salmon.

The observation that winter ulcer occurs mainly when water temperatures are low may reflect the decreased reparative and regenerative ability that fish possess at these temperatures (Roberts 1975). However, impaired immune responses at low water temperatures should also be considered. A possible low 
optimum-growth temperature for the isolated bacteria may also influence the time of the year when winter ulcer is most common.

Skin ulcers have been described previously in farmed Atlantic salmon, associated with an infection with a Cytophaga-like bacterium (Kent et al. 1988). One of the predisposing factors for the development of skin ulcers was considered to be mechanical skin damage (Kent et al. 1988). In this context, it should be noted that farmed Atlantic salmon in Norway are kept in densely populated net-pens, with up to $40 \mathrm{~kg}$ fish biomass per $\mathrm{m}^{3}$, and the risk of traumatic injury is obvious. The presence of ectoparasites such as Trichodina sp., Ichtyobodo necator, as well as salmon lice, may also cause slight skin irritation that could act as a predisposing factor for the establishment of a skin infection. Further to this, it has been reported that several fish parasites may serve as vectors of different infections (Cusack \& Cone 1986). Thus, the isolation of Vibrio sp. 1 and Vibrio sp. 2 from salmon lice may be of some relevance, although conclusive evidence that salmon lice can act as true vectors of the condition remains to be demonstrated.

A recent study proposed that the typical lesions of winter ulcer resulted from thrombosed dermal vessels and the subsequent formation of subepidermal vesicles (Salte et al. 1994). In the present study, small thrombi-like formations were also observed in small venules in the dermis, but only in the chronic stages of the disease. On the basis of our results, however, bacteria were clearly involved in the etiology. This conclusion is supported by the results obtained from cohabitation and inoculation experiments, and by the presence of bacteria in the lesions in the early stages of the disease. However, the pathogenesis is still poorly understood and attention should be paid to predisposing factors and other mechanisms accompanying the development of the typical lesions, apart from those already discussed, such as exogenous enzymes released from growing bacteria.

In conclusion, infection with Vibrio sp. seems to be of etiological importance in winter ulcer in Atlantic salmon since the disease can be reproduced experimentally and injection was not required to produce disease and mortality.

Acknowledgements. This project was supported by Norwegian Fisheries Research Council grant no. 747-005-1401. The authors thank Drs M. Valheim, L. K. Borgan, D. G. Markeng, P. A. Skagseth, O. Pettersen, and S. Sxvatdal for excellent cooperation during sampling and the transmission experiments, and Ms C. Fjellvang and Ms R. Terland for technical assistance in the laboratory.

\section{LITERATURE CITED}

Anon (1991) RAPP. The Royal Norwegian Ministry of Agriculture, Department of Veterinary Services, Oslo

Baumann P, Schubert RHW (1984) Family II. Vibrionaceae Veron 1965, 5245 AL. In: Krieg NR, Holt JG (eds) Bergey's manual of systematic bacteriology, Vol 1. The Williams and Wilkins Co, Baltimore, p 516-550

Colwell RR, Grimes DJ (1984) Vibrio diseases of marine fish populations. Helgoländer Meeresunters 37:265-287

Cusack R, Cone DK (1986) A review of parasites as vectors of viral and bacterial diseases of fish. J Fish Dis 9:169-171

Egidius E, Wiik R, Andersen K, Hoff KA, Hjeltnes B (1986) Vibrio salmonicida sp. nov., a new fish pathogen. Int $J$ Syst Bacteriol 36:518-520

Espelid S, Holm KO, Hjelmeland $\mathrm{K}$, Jorgensen $\mathrm{T}$ (1988) Monoclonal antibodies against Vibrio salmonicida: the causative agent of coldwater vibriosis ('Hitra disease') in Atlantic salmon, Salmo salar L. J Fish Dis 11:207-214

Evensen $\varnothing$ (1993) An immunohistochemical study on the cytogenetic origin of pulmonary multinucleate giant cells in porcine dermatosis vegetans. Vet Pathol 31:162-170

Evensen $\varnothing$. Espelid S, Håstein T (1991) Immunohistochemical identification of Vibrio salmonicida in stored tissues of Atlantic salmon Salmo salar from the first known outbreak of cold-water vibriosis ('Hitra disease'). Dis aquat Org 10: $185-189$

Holm KO (1985) Isolering og karakterisering av Vibriobakterier fra laks (Salmo salar L.) med Hitrasyke. [Isolation and characterization of Vibrio-bacteria from Atlantic salmon (Salmo salar L.) suffering from 'Hitra disease']. Thesis, Univ of Tromsø

Holt RA, Rohovec JS, Fryer JL (1993) Bacterial cold-water disease. In: Inglis $V$, Roberts RJ, Bromage NR (eds) Bacterial diseases of fish. Blackwell Scientific, London, p 3-22

Hsu S, Raine L, Fanger H (1981) Use of avidin-biotin-peroxidase complex $(A B C)$ in immunoperoxidase techniques: a comparison between $\mathrm{ABC}$ and unlabelled antibody (PAP) procedures. J Histochem Cytochem 29:577-580

Jensen NJ, Larsen JL (1979) The ulcus-syndrome in cod (Gadus morhua). I. A pathological and histopathological study. Nord vet Med 31:221-228

Jensen NJ, Bloch B, Larsen JL (1979) The ulcus-syndrome in cod (Gadus morhua). III. A preliminary virological report. Nord vet Med 31:436-442

Jensen NJ, Larsen JL (1982) The ulcus-syndrome in cod (Gadus morhua). IV. Transmission experiments with two viruses isolated from cod and Vibrio anguillarum. Nord vet Med 34:136-142

Kent ML, Dungan CF, Elston RA, Holt RA (1988) Cytophaga $\mathrm{sp}$. (Cytophagales) infection in seawater pen-reared Atlantic salmon Salmo salar. Dis aquat Org 4:173-179

Larsen JL, Jensen NJ (1979) The ulcus-syndrome in cod (Gadus morhua). II. A bacteriological investigation. Nord vet Med 31:289-296

Lorenzen E, Dalsgaard I. From J, Hansen EM, Horlyck V, Korsholm H, Mellergaard S. Olesen NJ (1991) Preliminary investigations of fry mortality syndrome in rainbow trout. Bull Eur Ass Fish Path 11:77-79

Lorenzen E, Karas N (1992) Detection of Flexibacter psychrophilus by immunofluorescence in fish suffering from fry mortality syndrome: a rapid diagnostic method. Dis aquat Org 13:231-234

Lunder T (1990) Vintersår [Winter ulcer]. In: Poppe TT (ed) Fiskehelse [Fish health]. John Grieg Forlag, Bergen, p 304-305 
Melby HP, Krogsrud J, Stenwig H (1991) All commercial Atlantic salmon seawater farms in Norway harbour carriers of infectious pancreatic necrosis virus (IPNV). In: Fryer $\mathrm{JL}$ (ed) Proceedings of the 2nd international symposium on viruses in lower vertebrates. Oregon State University, Corvallis, p 211-217

Pacha RE, Ordal EJ (1970) Myxobacterial diseases of salmonids. Am J Fish Special Publ No 5:243-257

Petrusz P (1983) Essential requirements for the validity of immunocytochemical staining procedures. J Histochem Cytochem 31:177-179

Roberts RJ (1975) The effect of temperature on diseases and their histopathological manifestations in fish. In: Ribelin WR, Migaki G (eds) The pathology of fishes. University of Wisconsin Press, Madison, p 477-496

Roberts RJ, Horne MT (1978) Bacterial meningitis in farmed

Responsible Subject Editor: T. Evelyn, Nanaimo, B.C., Canada rainbow trout Salmo gairdneri Richardson affected with chronic pancreas necrosis. J Fish Dis 1:157-164

Salte R, Rørvik KA, Reed E (1994) Winter ulcers of the skin in Atlantic salmon Salmo salar L.: pathogenesis and possible aetiology. J Fish Dis 17:661-665

Schiewe MH, Trust TJ, Crosa JH (1981) Vibno ordalii sp. nov.: a causative agent of vibriosis in fish. Curr Microbiol 6:343-348

Thorud K, Lunder T, Wiik S, Engeland E (1990) Electron microscopic observations of EIBSV-like particles and two intraerythrocytic virus-like particles different from EIBSV in Atlantic salmon, Salmo salar, in Norway. Bull Eur Ass Fish Pathol 10:95-97

West PA. Colwell RR (1983) Identification and classification of Vibronaceae - an overview. In: Colwell RR (ed) Vibrios in the environment. John Wiley and Sons, New York, p $285-364$

Manuscript first received: October 14, 1993

Revised version accepted: February 21, 1995 